\title{
SISTEM PENGELOLAAN PENGADUAN DALAM MENINGKATKAN KEPUASAN PELANGGAN PADA PDAM TIRTA KAHURIPAN KABUPATEN BOGOR
}

\section{COMPLAINT MANAGEMENT SYSTEM TO IMPROVE CUSTOMER SATISFACTION IN PDAM TIRTA KAHURIPAN KABUPATEN BOGOR}

\author{
Yuni Wulandari ${ }^{1}$, Denny Hernawan ${ }^{2}$, Irma Purnamasari \\ ${ }^{1}$ Jurusan Ilmu Administrasi Negara Fakultas Imu Sosial dan Ilmu Politik Universitas Djuanda, Jl.Tol \\ Ciawi No 1, Kotak Pos 35 Bogor 16770 \\ 2 Jurusan Ilmu Administrasi Negara Fakultas Imu Sosial dan Ilmu Politik Universitas Djuanda, Jl.Tol \\ Ciawi No 1, Kotak Pos 35 Bogor 16770 \\ ${ }^{3}$ Jurusan Ilmu Administrasi Negara Fakultas Imu Sosial dan Ilmu Politik Universitas Djuanda, Jl.Tol \\ Ciawi No 1, Kotak Pos 35 Bogor 16770
}

(Diterima oleh Dewan Redaksi: 01-08-2015)

(Dipublikasikan oleh Dewan Redaksi: 01-10-2015 )

\begin{abstract}
Regional Water Company (PDAM) is a company that is managed by the Local Government to operate as a body of community service that is selling services and trust in society. PDAM has to must still understand the behavior and wishes of the customers in the utilization of services of drinking water and the discretion of the company in the form term of service standards set, so as to provide a good service that causes customers to be satisfied.

One of the PDAM in Indonesia is PDAM Tirta Kahuripan located in Bogor. PDAM Tirta Kahuripan is often get complaints from their customers. $\theta$ f the Many customers who complained about the poor service system so far is are leaky pipe impact on the high notes of erroneous meter, water quality is still dirty muddy, and sluggish handling of a complaint.

The aim of research is to find out a complaint management system in order to improve customer satisfaction at PDAM Tirta Kahuripan.

The theory used to analyze a system of customer complaints is the-referring to the Minister of Administrative Reform and Bureaucratic Reform No. 3 Year of 2015 on the Road Map Development Complaints Public Service Nationwide with 3 sizes of complaint management : outcomes, targets, and programs. While, improving customer satisfaction using Fandi Tjiptono and Gregory Cahndra theory (2006: 130) with four dimensions to measure customer satisfaction : the system of complaints and suggestions, Customer satisfaction Survey, Ghost Shopping (Shadow Customer), and Customer Switching Analysis.

Research methods used in this research is descriptive quantitative method using questionnaires / questionnaire and interviews as the main instrument to collect data.

The results showed that the management of customer complaints in accordance with to existing procedures with the acquisition of a score of is 3.32 according to the with category of interpretation of the category is as quite good enough (moderate). Meanwhile, the results of data analysis by increasing customer satisfaction PDAM Tirta Kahuripan obtained a score of is 2.83 in the category with category of interpretation as good enough (moderate).

Nevertheless, But there is a needs to be have a system or application that can be accessed in to the customer complaints and the organizers therefore PDAM can respond and follow complaint subsequently.
\end{abstract}

Keywords : Complaint Management System, Customer Satisfaction 


\begin{abstract}
ABSTRAK
YUNI WULANDARI, Program Studi Administrasi Negara, Fakultas Ilmu Sosial dan Ilmu Politik, Universitas Djuanda Bogor, 2016, Sistem Pengelolaan Pengaduan dalam Meningkatkan Kepuasan Pelanggan di Perusahaan Daerah Air Minum (PDAM) Kabupaten Bogor, Pembimbing 1 : Denny Hernawan, Drs., MA, Pembimbing 2 : Irma Purnamasari, S.Sos., M.Si.

Perusahaan Daerah Air Minum (PDAM) merupakan perusahaan yang dikelola oleh Pemerintah Daerah yang dalam pengoperasiannya sebagai badan pelayanan masyarakat yaitu menjual jasa dan kepercayaan terhadap masyarakat, harus tetap memahami perilaku dan keinginan para pelanggan dalam pemanfaatan jasa layanan air minum dan kebijaksanaan perusahaan berupa standar pelayanan yang ditetapkan, sehingga dapat memberikan pelayanan yang baik yang menyebabkan pelanggan menjadi puas.

Salah satu PDAM di Indonesia adalah PDAM Tirta Kahuripan yang berada di Kabupaten Bogor. PDAM Tirta Kahuripan sering mendapatkan pengaduan dari pelanggan. Dari banyaknya pelanggan yang mengeluhkan buruknya sistem pelayanan selama ini yaitu pipa yang bocor berdampak pada tingginya catatan meteran yang keliru, kualitas air yang masih kotor keruh serta penanganan pengaduan yang lamban.

Tujuan penelitian untuk mengetahui sistem pengelolaan pengaduan dalam meningkatkan kepuasan pelanggan pada PDAM Tirta Kahuripan.

Teori yang digunakan dalam menganalisis sistem pengaduan pelanggan adalah pengacu pada Peraturan Menteri Pendayagunaan Aparatur Negara dan Reformasi Birokrasi Nomor 3 Tahun 2015 tentang Road Map Pengembangan Pengelolaan Pengaduan Pelayanan Publik Secara Nasional dengan 3 ukuran pengelolaan pengaduan outcome, target, program, sedangkan untuk meningkatkan kepuasan pelanggan menggunakan teori Fandi Tjiptono dan Gregorius Cahndra (2006:130) dengan 4 dimensi untuk mengukur kepuasan pelanggan, yaitu sistem pengaduan dan Saran, Survei Kepuasan pelanggan, Ghost Shopping (Pelanggan Bayangan), Analisa Pelanggan yang Beralih.

Metode Penelitian yang digunakan dalam penelitian ini adalah metode deskriptif kuantitatif dengan menggunakan kuesioner/angket dan wawancara sebagai instrumen utama untuk mengumpulkan data

Hasil penelitian menunjukkan pengelolaan pengaduan pelanggan sesuai dengan prosedur yang ada dengan perolehan skor 3,32 yang menurut penafsiran dengan katagori CUKUP BAIK sedangkan hasil analisis data cara meningkatkan kepuasan pelanggan PDAM Tirta Kahuripan diperoleh skor 2,83 dengan katagori CUKUP BAIK.

Namun, perlu adanya sistem atau aplikasi yang bisa diakses pelanggan dalam menyampaikan pengaduan dan pihak penyelenggara- PDAM dapat merespon serta memenindaklanjuti pengaduan tersebut.
\end{abstract}

Kata kunci : Sistem Pengelolaan Pengaduan, Kepuasan Pelanggan.

Yuni Wulandari, 2016. Sistem Pengelolaan Pengaduan Dalam Meningkatkan Kepuasan Pelanggan Pada Pdam Tirta Kahuripan Kabupaten Bogor. 


\section{PENDAHULUAN}

penyelenggara pelayanan publik sebagai upaya untuk pemenuhan kebutuhan dan keperluan penerima pelayanan. Perusahaan Daerah Air Minum (PDAM) merupakan perusahaan yang dikelola oleh Pemerintah Daerah yang dalam pengoperasiannya sebagai badan pelayanan masyarakat yaitu menjual jasa dan kepercayaan terhadap masyarakat, harus tetap memahami perilaku dan keinginan para pelanggan dalam pemanfaatan jasa layanan air minum dan kebijaksanaan perusahaan berupa standar pelayanan yang ditetapkan, sehingga dapat memberikan pelayanan yang baik yang menyebabkan pelanggan menjadi puas. Mengingat air merupakan kebutuhan pokok dalam kehidupan sehari-hari, air memiliki peranan penting untuk mendukung kemakmuran dan kesejahteraan masyarakat. Salah satu PDAM di Indonesia adalah PDAM Tirta Kahuripan yang berada di Kabupaten Bogor.

PDAM Tirta Kahuripan mendapatkan penghargaan Persatuan Perusahaan Air Minum Seluruh Indonesia (Perpamsi) Award 2015 yang diserahkan langsung oleh Presiden Jokowi. Meskipun PDAM Tirta Kahuripan sudah meraih prestasi, PDAM ini sering mendapatkan pengaduan dari pelanggan. Dari banyaknya pelanggan yang mengeluhkan buruknya sistem pelayanan selama ini yaitu pipa yang bocor meningkat terhadap catatan meteran yang keliru, kualitas air yang masih kotor keruh serta penanganan pengaduan yang lamban. Banyaknya pelanggan yang mengeluh, hal ini sebagaimana terlihat dalam data pengaduan pelanggan sebagai berikut :
Tabel 1

Daftar Pengaduan Pelanggan Tahun 2016

\begin{tabular}{c|c|c|c|c|c|c|}
\hline \multirow{2}{*}{ No } & \multirow{2}{*}{ Bulan } & \multicolumn{3}{|c|}{ Jenis Keluhan } & \multirow{2}{*}{ Jumlah } \\
\cline { 3 - 6 } & & $\mathbf{1}$ & $\mathbf{2}$ & $\mathbf{3}$ & $\mathbf{4}$ & Keluhan \\
\hline 1 & Januari & 12 & 8 & 4 & 6 & 30 \\
\hline 2 & Febuari & 4 & 5 & 1 & 8 & 29 \\
& & & & 2 & & \\
\hline 3 & Maret & 3 & 4 & 3 & 3 & 13 \\
\hline
\end{tabular}

Sumber : Hasil penelitian, 2016

Jenis Jeluahan

1. Air tidak mengalir

2. Meteran rusak

3. Pipa Bocor

4. Adminitrasi pencatatan tagihan

Padahal dalam penyelenggaraan pelayanan air minum, pelanggan mempunyai hak sebagai berikut:

Dalam Undang-Undang Nomor 25 tahun 2009 tentang Pelayanan Publik mengamanatkan penyelenggara wajib memberikan akses seluas luasnya kepada masyarakat untuk memberikan masukan kepada penyelenggara atas pemberian layanannya. Oleh karena itu, pengelolaan pengaduan harus dikelola dengan baik yaitu antara lain menyediakan sarana pengaduan, menugaskan pelaksana yang berkompeten, menangani pengaduan dan menindak lanjuti pengaduan.

Mengacu pada Peraturan Menteri Pendayagunaan Aparatur Negara dan Reformasi Birokrasi Republik Indonesia Nomor 3 Tahun 2015 Tentang Road Map Pengembangan Sistem Pengelolaan Pengaduan Pelayanan Publik Nasional.

Dengan adanya SP4N ini diharapkan pengaduan masyarakat mengenai pelayanan publik dapat ditangani dengan cepat, transparan, dan akuntabel sesuai dengan kewenangan masing-masing penyelenggara dan mendorong peningkatan kinerja penyelenggara dan pelaksana pelayanan publik dalam pengelolaan pengaduan pelayanan publik. 
Pengaduan dari pelanggan harus diterima suatu perusahaan sebagai sebuah hadiah, dengan adanya pengaduan maka perusahaan dapat harus terus melakukan perbaikan terhadap pelayanan yang diberikan. Besar atau kecilnya suatu pengaduan bila tidak dikelola dengan cepat dan baik akan berdampak kepada kepuasaan pelanggan yang diberikan perusahaan. Untuk melayani setiap pengaduan, PDAM Tirta Kahuripan mempunyai 5 unit bagian khusus yang berada dibawah bagian khusus yang berada dibawah direktur teknik dan direktur administrasi yaitu bagian kepala bagian humas kepala bagian produksi kepala bagian distribusi kepala seksi hubungan langganan staf seksi hubungan langganan dan setiap pengaduan yang masuk akan dipilah sesuai dengan jenis pengaduan untuk ditangani oleh unit unit yang bersangkutan.

Berdasarkan hal tersebut, penulis ingin meneliti sejauh mana pelaksanaan pengelolaan pengaduan pelanggan yang dilakukan di perusahaan pemerintah dalam hal ini penaganan pengaduandengan mengambil judul: Sistem Pengelolaan Pengaduan Dalam Meningkatkan Kepuasan Pelanggan Pada PDAM Tirta Kahuripan Kabupaten Bogor

\section{MATERI DAN METODE}

Peraturan Menteri Pendayagunaan Aparatur Negara dan Reformasi Birokrasi Nomor 3 Tahun 2015 tentang Road Map Pengembangan Pengelolaan Pengaduan Pelayanan Publik Secara Nasional. Berikut tahapan-tahapan dalam pelaksanaan dan pengembangan SP4N tersebut.

Tahapan pembangunan SP4N dilakukan dalam 3 (tiga) tahun, sebagai berikut Periode Tahun 2015

\section{Outcome}

- Terwujudnya penyelenggara yang mampu merespon dan menindaklanjuti keluhan/pengaduan.

- Kesadaran masyarakat meningkat dan berani menyampaikan pengaduan pelayanan publik.

2. Target

Seluruh Penyelenggara dalam hal ini Kementerian/Lembaga dan Pemerintah Daerah sudah memiliki pengelolaan pengaduan yang efektif.

\section{Program}

- Penyiapan sarana/prasarana pengaduan yang mudah diakses oleh masyarakat.

- Peningkatan kapasitas individu/pengelola, organisasi, dan sistem pengelolaan pengaduan pelayanan publik.

- Pembentukan kelembagaan pengaduan dan pengelola pengaduan yang kompeten.

- Pembentukan mekanisme dan prosedur pengaduan pelayanan publik.

- Pemantauan secara rutin.

- Pelaksanaan Evaluasi secara periodik

Dan untuk mengkatkan kepuasan pelanggan Fandi Tjiptono dan Gregorius Cahndra (2006:130) mengemukakan ada empat dimensi untuk mengukur kepuasan pelanggan, yaitu :

1. Sistem pengaduan dan Saran

Industri yang berwawasan pelanggan akan menyediakan formulir bagi pelanggan untuk melaporkan kesukaan dan keluhannya.

2. Survei Kepuasan pelanggan

Industri tidak dapat menggunakan tingkat pengaduan sebagi ukuran kepuasan pelanggan.

3. Ghost Shopping (Pelanggan Bayangan)

Pelanggan bayangan adalah menuruh orang berpura-pura menjadi pelanggan dan melaporkan titik-titik kuat maupun titik-titik lemah yang dialami waktu 
membeli produk dari industri sendiri maupun saingannya.

4. Analisa Pelanggan yang Beralih

Industri dapat menghubungan pelanggan yang tidak membeli lagi atau berganti pemasok untuk mengetahui penyebabnya.

Metode yang digunakan dalam penelitian ini adalah metode penelitian deskriptif dengan pendekatan kuantitatif. Masyhuri (2008:34) menjelaskan bahwa penelitian yang bersifat deskriptif merupakan penelitian yang memberi gambaran secermat mungkin mengenai suatu individu, keadaan, gejala atau kelompok tertentu. Penelitian deskriptif menggambarkan perilaku, pemikiran, atau perasaan suatu kelompok atau individu. Menurut Sugiyono (2011:11) metode deskriptif adalah penelitian yang dilakukan untuk mengetahui nilai variabel mandiri, baik satu variabel atau lebih (independen) tanpa membuat perbandingan atau menghubungkan antara variabel satu dengan variabel lain.

Tujuan penelitian deskriptif yaitu untuk mengetahui atau menggambarkan kenyataan dari kejadian yang diteliti atau penelitian yang dilakukan terhadap variabel mandiri atau tunggal, yaitu tanpa membuat perbandingan atau menguhubungkan dengan variabel lain. Sehingga memudahkan penulis untuk mendapatkan data objektif dalam rangka mengetahui dan memahami pelaksanaan penanganan keluhan di PDAM Tirta Kahuripan Kabupaten Bogor. Sedangkan dasar penelitiannya membagi lembaran angket dalam bentuk pertanyaan kepada pegawai yang mengelola pengaduan pelanggan dan pelanggan yang mengadukan keluhannya.

\section{TEKNIK}

\section{PENARIKAN SAMPEL}

Populasi dan Sampel

Populasi menurut Sugiono (2011:90) populasi merupakan wilayah generalisasi yang terdiri dari objek/subjek yang mempunyai kualitas dan karakteristik tertentu yang ditetapkan oleh peneliti untuk dipelajari dan kemudian ditarik suatu kesimpulannya. Populasi yang digunakan dalam penelitian ini adalah pegawai PDAM Tirta Kahuripan yang berjumlah 479 orang dan pelanggan PDAM Tirta Kahuripan

Sampel Menurut Prof. Sugiyono (2011:91), sampel adalah bagian dari jumlah dan karakteristik yang dimiliki oleh populasi tersebut. Untuk itu sampel yang diambil dari populasi harus betul-betul representative (mewakili). Dengan kata lain sampel adalah sebagian atau wakil dari populasi yang dapat diteliti (Hasan, 2002:58)

Dalam penelitian ini penulis menggunakan metode nonprobability sampling yaitu teknik pengambilan sampel yang tidak memberikan peluang atau kesempatan sama bagi setiap unsur atau anggota populasi untuk dipilih menjadi sampel. Prof. Sugiono mengemukakan bahwa salah satu sampel yang termasuk nonprobability sampling adalah sampling purposive adalah teknik penentuan sampel dengan pertimbangan tertentu dipandang cocok untuk penelitian ini. Adapun dalam penelitian ini penulis menentukan ciri dan karakteristik yaitu pegawai PDAM yang mengelola pengaduan pelanggan.

\section{Tabel 2}

Purposive Sampling Penelitian

\begin{tabular}{|c|c|c|}
\hline No. & Keterangan & Jumlah \\
\hline 1 & Kepala Bagian Humas & 1 \\
\hline 2 & $\begin{array}{l}\text { Kepala Bagian } \\
\text { Produksi }\end{array}$ & 1 \\
\hline 3 & $\begin{array}{l}\text { Kepala Bagian } \\
\text { Distribusi }\end{array}$ & 1 \\
\hline 4 & $\begin{array}{l}\text { Kepala Seksi } \\
\text { Hubungan langganan }\end{array}$ & 1 \\
\hline 5 & $\begin{array}{l}\text { Staf Seksi Hubungan } \\
\text { langganan }\end{array}$ & 9 \\
\hline \multicolumn{2}{|c|}{$\begin{array}{c}\text { Jumlah pegawai yang } \\
\text { mengelola pengaduan } \\
\text { pelanggan }\end{array}$} & 13 \\
\hline
\end{tabular}

Sumber : PDAM Tirta Kahuripan

Sampel yang digunakan dalam penelitian ini adalah pegawai PDAM yang mengelola pengaduan pelanggan yaitu 
dengan jumlah 13 orang. Sedangkan untuk sampel pelanggan penulis menggunakan Sampling Insidental menurut Prof. Sugiyono Sampling Insidental adalah teknik penentuan sampel berdasarkan kebetulan. Penulis menentukan siapa aja yang penulis temui saat berada di Kantor Pusat PDAM Tirta Kahuripan.

\section{JENIS DAN TEKNIK PENGUMPULAN DATA}

Untuk mendapatkan data yang relevan dan sesuai dengan kebutuhan yang berkaitan dengan penelitian, maka metode pengumpulan data yang diguanakan adalah sebagai berikut :

a. Studi kepustakaan

Dalam pengumpulan data penulis menggunakan data sekunder yang bersumber dari buku-buku, majalah dan peraturan perundang-an yang berlaku

b. Studi Lapangan

Penelitian studi lapangan adalah suatu teknik penelitian yang digunakan untuk mengumpulkan data (tempat penelitian) secara langsung. Teknik ini dilakukan dengan penyebaran angket (kueisioner) atau daftar pertanyaan kepada seluruh responden yang sudah ditentukan jawaban dan melakukan wawancara yaitu menggali informasi secara mendalam. Hasil wawancara tersebut digunakan sebagai pembanding.

Menurut Sugiyono (2011 : 107), skala Likert adalah yang mempunyai gradasi yang sangat positif sampai sangat negatif dan digunakan untuk mengukur sikap, pendapat, serta persepsi seseorang atau sekelompok orang tentang fenomena sosial, juga untuk mengAnalisis kuantitatif dengan menggunakan skor untuk pertanyaan-pertanyaan tersebut dengan klasifikasi penilaian sebagai berikut :

Tabel. 3

Klasifikasi Jawaban Skala Likert

\begin{tabular}{|c|c|c|}
\hline Jawaban & Klasifikasi & Skor \\
\hline A & Selalu & 5 \\
\hline B & Sering & 4 \\
\hline C & Kadang-Kadang & 3 \\
\hline
\end{tabular}

\begin{tabular}{|c|c|c|}
\hline $\mathrm{D}$ & $\begin{array}{c}\text { Hampir Tidak } \\
\text { Pernah }\end{array}$ & 2 \\
\hline $\mathrm{E}$ & Tidak Pernah & 1 \\
\hline
\end{tabular}

Diharapkan dalam penelitian ini diperoleh data yang seakurat mungkin guna pemaparan hasil penelitian secara lengkap dan jelas, serta dapat mengungkap apa yang ada pada realitanya.

Karena alternatif jawaban menggunakan urutan kedudukan yang mengantarkan perbedaan tingkat skala dari angka yang tertinggi sampai ke angka terendah, maka untuk menentukan kriteria penafsiran harus dicari dulu interval antara satu kriteria dengan kriteria lainnya, sebagai berikut :

I = Skor Tertinggi - Skor Terendah / jumlah Maka I $=5-1 / 5=0,8$

Sehingga dapat diperoleh kriteria penafsiran sebagai berikut :

\begin{tabular}{|c|c|c|}
\hline NO. & Skor & Kriteria \\
\hline 1. & $\begin{array}{c}4,24- \\
5,00\end{array}$ & Sangat Baik \\
& $3,43-$ & Baik \\
\hline 2. & 4,23 & \\
\hline 3. & $2,62-$ & Sedang \\
& 3,42 & \\
\hline 4. & $1,81-$ & Buruk \\
& 2,61 & \\
\hline 5. & $1,00-$ & Sangat \\
& 1,80 & Buruk \\
\hline
\end{tabular}

Dalam penelitian ini pendeskripsian dan analisis data variabel penelitian diambil dengan cara menyusun data yang diperoleh kedalam variabel frekuensi tersendiri. Hal ini dimaksudkan untuk mendapatkan deskripsi atau gambaran dan karakteristik dari responden penelitian. Langkah langkah analisis data sebagai berikut:

- Data koesioner yang terkumpul dihitung distribusi frekuensinya (f) dari masingmasing pilihan jawaban

- Setelah itu dihitung presentase dari masing-masing pilihan jawaban dengan menggunakan rumus : 


$$
\mathrm{P}=\frac{\mathrm{f} \times 100 \%}{\sum \mathrm{n}}
$$

Keterangan :

$\mathrm{P}=$ Presentase

$\mathrm{F}=$ Frekuensi

$\sum \mathrm{n}=$ Jumlah sample

Setelah melakukan presentase data kemudian data diolah berdasarkan hasil jawaban responden melalui angket dengan menggunakan rumus Weight Mean Score (WMS) yang dikemukakan oleh Sanbard Lambovitz dan Robet Hageldorn yang dialih bahasakan oleh Bakri Siregar (1993:34), yaitu dilakukan pembobotan untuk setiap pilihan jawaban sebagai berikut :

$$
\mathrm{M}=\frac{\sum(\mathrm{f}(\mathrm{x}))}{\mathrm{n}}
$$

Keterangan :

$\mathrm{M}=$ Perolehan Angka Kriteria Penafsiran

$\mathrm{F}=$ Frekuensi jawaban

$\mathrm{x}=$ Pembobotan

$\mathrm{n}=$ Jumlah responden

\section{$\Sigma=$ penjumlahan}

\section{HASIL DAN PEMBAHASAN}

Berdasarkan hasil penelitian, Sistem pengelolaan pengaduan dalam meningkatkan kepuasan meningkatkan kepuasan pelanggan.

Prosedur pengelolaan pengaduan pelanggan pada PDAM Tirta Kahuripan yaitu :

a. Penanganan pengaduan pada jam kerja

- Menyiapkan formulir isian pengaduan

- Mencatat pengaduan pelanggan yang disampaikan secara langsung, melalui telpon, media masa cetak, media masa elektonik, surat, faks dan email

- Khusus pengaduan pelanggan yang dtang secara langsung atau melalui telepon, bila merasa belum puas atas penjelasan staf Humas konsultasikan dengan Ka. Sie Hubungan pelanggan

- Ka. Sie Hubungan pelanggan mengambil alih penanganan penganduan pelanggan dan menjelaskan kembali dengan singkat, padat dan jelas

- Bila pengaduan bersifat teknis dan memerlukan pembuktian lapangan maka cari kesepakatan waktu untuk melakukan pengecekan lapangan dan bila diperlukan koordinasi dengan Kepala Bagian terkait misal Kepala Bagian Produksi untuk kualitas air

- Melaporkan setiap bulan penanganan pengaduan beserta upaya yang telah dilakukan kepada Direktur Umum, dan disiapkan oleh Ka. Sie Hublang

- Bila pengaduan tidak mampu diselesaikan oleh Kepala Bagian Humas maka dibuat laporan ke Dikrektur Umum bersifat administrasi dengan dan Direktur Teknik untuk pengaduan yang bersifat teknis

- Bila ada pengaduan pelanggan yang memerlukan keputusan dari Direksi maka Kepada Bagian Humas membuat Nota Dinas ke Direksi.

- Memonitor tindak lanjut penyelesaian oleh Ka. Sie Hubungan Pelanggan.

b. Penanganan Pengaduan Pelanggan lewat Media Masa Cetak, Media Masa Elektronik, Pos dan Email

- Bila melalui telepon, segera hubungi pelanggan tersebut dengan ramah, santun dan empati

- Bila tidak mencantumkan telepon namun mencantumkan alamat, kunjungi alamat tersebut untuk dilakukan kejelasan

c. Menyampaikan ucapan terima kasih dan penghargaan kepada pelanggan 


\begin{tabular}{|c|c|c|c|c|}
\hline & \multicolumn{2}{|c|}{$\begin{array}{l}\text { Angka Penafsiran } \\
\text { (M) }\end{array}$} & \multirow{2}{*}{$\begin{array}{l}\text { Nilai } \\
\text { Rata- } \\
\text { rata }\end{array}$} & \multirow{2}{*}{$\begin{array}{l}\text { Kriter } \\
\text { ia } \\
\text { penaf } \\
\text { siran }\end{array}$} \\
\hline & $\begin{array}{c}\text { Pegaw } \\
\text { ai }\end{array}$ & $\begin{array}{l}\text { Pelangg } \\
\text { an }\end{array}$ & & \\
\hline $\begin{array}{l}\text { Sistem } \\
\text { pengadaun } \\
\text { dan Saran }\end{array}$ & 4,23 & 3,60 & 3,19 & $\begin{array}{c}\text { Cukup } \\
\text { Baik }\end{array}$ \\
\hline Survei & 3,26 & 3,26 & 3,26 & $\begin{array}{c}\text { Cukup } \\
\text { Baik }\end{array}$ \\
\hline $\begin{array}{l}\text { Ghost } \\
\text { Shopping }\end{array}$ & 1 & 1 & 1 & $\begin{array}{l}\text { Tidak } \\
\text { Baik }\end{array}$ \\
\hline $\begin{array}{l}\text { Analisa } \\
\text { pelanggan } \\
\text { yang beralih }\end{array}$ & 3,61 & 2,73 & 3,17 & $\begin{array}{c}\text { Cukup } \\
\text { Baik }\end{array}$ \\
\hline Jumlah & 12,1 & 10,59 & 10,72 & \\
\hline $\begin{array}{c}\text { Jumlah Rata- } \\
\text { rata } \\
\mathrm{M}=\sum \text { skor / } \\
\text { Jumlah } \\
\text { Indikator }\end{array}$ & $\begin{array}{c}12,1 / \\
4= \\
3,02\end{array}$ & $\begin{array}{l}10,59 / \\
4=2,64\end{array}$ & & \\
\hline $\begin{array}{c}\text { Jumlah Rata - } \\
\text { rata kedua } \\
\text { responden }\end{array}$ & & 2,83 & & $\begin{array}{c}\text { Cuku } \\
\mathbf{p} \\
\text { Baik }\end{array}$ \\
\hline
\end{tabular}

Tabel 4

Rekapitulasi variabel sistem pengelolaan pengaduan yang dirumuskan secara jelas menurut responden pegawai dan pelanggan

Berdasarkan hasil perhitungan diatas kita dapat melihat bahwa sistem pengelolaan

\begin{tabular}{|c|c|c|c|c|}
\hline \multirow{2}{*}{ Dimensi } & \multicolumn{2}{|c|}{$\begin{array}{l}\text { Angka Penafsiran } \\
\text { (M) }\end{array}$} & \multirow{2}{*}{$\begin{array}{c}\text { Nilai } \\
\text { Rata- } \\
\text { rata }\end{array}$} & \multirow{2}{*}{$\begin{array}{c}\text { Kriteria } \\
\text { penafsira } \\
n\end{array}$} \\
\hline & Pegawai & $\begin{array}{l}\text { Pelang } \\
\text { gan }\end{array}$ & & \\
\hline Outcome & 4,07 & 3,10 & 3,58 & Baik \\
\hline Target & 3,53 & 3,60 & 3,56 & Baik \\
\hline Program & 3,91 & 3,26 & 3,58 & Baik \\
\hline Jumlah & 11,51 & 9,96 & 10,72 & \\
\hline $\begin{array}{c}\text { Jumlah Rata- } \\
\text { rata } \\
\mathrm{M}=\sum \text { skor / } \\
\text { Jumlah Indikator }\end{array}$ & $\begin{array}{c}11,51 / 3 \\
= \\
3,83\end{array}$ & $\begin{array}{c}9,96 / 3 \\
= \\
3,32\end{array}$ & & \\
\hline $\begin{array}{l}\text { Jumlah Rata - } \\
\text { rata kedua } \\
\text { responden }\end{array}$ & \multicolumn{3}{|c|}{$M=\sum$ skor $/$ Jumlah Indikator } & $\begin{array}{l}\text { Cukup } \\
\text { Baik }\end{array}$ \\
\hline
\end{tabular}

pengaduan sudah dikatagorikan baik.

Tabel 5

Rekapitulasi variabel meningkatkan kepuasaan pelanggan yang dirumuskan secara jelas menurut responden pegawai dan pelanggan
Berdasarkan hasil perhitungan diatas kita dapat melihat bahwa dalam meningkatkan kepuasaan pelanggan sudah dikatagorikan baik.

\section{KESIMPULAN DAN IMPLIKASI}

Dari penelitian mengenai Sistem Pengelolaan Pengaduan dalam meningkatkan kepuasa pelanggan dapat ditarik kesimpulan yaitu :

1. Peningkatan kapasitas pengelola dan sistem pengelolaan pengaduan sudah sangat baik dengan pegawai PDAM Tirta kahuripan yang kompenten dalam menangani pengaduan dari pelanggan dan dilakukan sesuai dengan prosedur

2. Belum terwujudnya penyelenggara yang mampu merespon dan menindaklanjuti pengaduan karena masih ada pelanggan yang tidak puas dalam pelayanan pengaduan

3. Tetapi tidak semua pelanggan mau menyampaikan pengaduannya

4. Ketersediannya sarana dan prasarana pengaduan yang mudah diakses oleh pelanggan

5. Belum adanya sistem/aplikasi yang mengelola pengaduan pelanggan

6. Individu yang cukup kompeten dalam menaggapi dan menangani pengaduan pelanggan

7. Dalam meningkatkan kepuasan pelanggan PDAM tirta kahuripa sudah melaukan survei kepuasan pelanggan rutin setiap tahun sebanyak 2 kali

\section{DAFTAR PUSTAKA}

Sugiyono. (2011) Metode Penelitian Administrasi. Bandung, Alfabeta

Tjiptono, Fandy. (2005) Pemasaran Jasa. Bayumedia Publishing, Malang 
Tjiptono, Fandy \& Chandra, Gregorius. (2006) Manajemen Pelayanan Jasa. ANDI Yogyakarta

Tjiptono, Fandy \& Anastasia Diana. (2003) Total Quality Management. ANDI Yogyakarta

\section{Sumber Dokumen}

Undang-Undang Nomor 25 tahun 2009 Pasal 36 dan 37 tentang Pelayanan Publik.

Peraturan Presiden Nomor 76 Tahun 2013 Tentang Pengelolaan Pengaduan Pelayanan Publik, yang mengisyaratkan dibentuknya Sistem Pengelolaan Pengaduan Pelayanan Publik Nasional (SP4N)

Peraturan Menteri Pendayagunaan Aparatur Negara dan Reformasi Birokrasi Nomor 3 Tahun 2015 tentang Road Map Pengembangan Pengelolaan Pengaduan Pelayanan Publik Secara Nasional

Undang-undang Republik Indonesia Nomor 25 Tahun 2000 tentang Program Pembangunan Nasional (PROPENAS)

Hak Pelanggan Perusahaan Air Minum PDAM Tirta Kahuripan Kabupanten Bogor

Prosedur Penanganan Pengaduan Pelanggan PDAM Tirta Kahuripan Kabupaten Bogor. 